\title{
A vasúti szektor védelmi lehetôségei terrorakciók ellen
}

\author{
A vasúti alágazat, mint a közlekedési rendszer eleme, „puha célpont” \\ lehet a terroristák számára akcióik végrehajtása szempontjából. \\ A könnyü hozzáférhetőség, a jelentős számú utas, a nagy tömegú \\ (olykor veszélyes) áruk szállítása, és a várhatóan magas áldozatszám \\ könnyen arra késztetheti a terrorcsoportokat, hogy akcióikat a vasút \\ területén hajtsák végre. Az előzőek miatt a védekezés szükséges és \\ elvárt, mind az utazóközönség, mind a fuvaroztató felek, mind pedig \\ az állam részéről.
}

DOI 10.24228/KTSZ.2019.5.5

\author{
Lévai Zsolt \\ tudományos munkatárs \\ Közlekedéstudományi Intézet Nonprofit Kft. \\ e-mail: levai.zsolt@kti.hu
}

\section{BEVEZETÉS}

A 20. század vége és a 21. század hadviselése leginkább már nem az országok közötti háborúkról szól, hanem a terrorizmus elleni harc a fö akcióterület. Az országokon átnyúló nemzetközi terrorszervezetek bárhol képesek támadást indítani a lakosság vagy egyes intézmények ellen súlyos károkat okozva az adott ország életében. E szervezetek számára minden célpont lehet, ahol a károkozás számottevő mértéküre nőhet. Képesek felkutatni azokat a pontokat, amelyek sebezhetősége könnyü, így az ellenük intézett támadás számukra megfelelő „eredményt" hozhat. Ilyenek a közlekedés elemei is. A nagy terminálokon sok ember mozog, mindenki mozgását ellenőrizni szinte lehetetlen, a tömegben könnyen megbújhatnak a terroristák, így a tervezett merénylet végrehajtása könynyebb. Főleg a fanatikus, magukat is feláldozó terroristák helyzete egyszerübb egy öngyilkos merénylet során. Ugyancsak könnyebbséget je- lent a közlekedési pályák hossza. A vasút sok kilométeren át kígyózik szerte a világban, ugyanakkor elég lehatárolt területen (meghatározott pályán) közlekednek a vonatok, ami megkönynyíti a pokolgépek megfelelő elhelyezését. A vasúti pályák és az autópályák minden egyes méterét bekamerázni és a nap minden egyes percében azokat felügyelni szintén lehetetlen. Így akadhatnak olyan helyek és időpontok, ahol és amikor egy terrortámadás megfelelően előkészíthető és kivitelezhető. Ezek alapján elmondhatjuk, hogy a terrorcsoportok célpontjaivá válhatnak a közösségi közlekedés eszközei és mütárgyai:

- a jármüvek,

- a repülöterek,

- a vasútállomások,

- a kikötők,

- a hidak,

- az alagutak,

- a forgalomirányító központok. 
A közlekedési rendszerek átszövik a gazdasági, társadalmi élet egészét. Nem létezik egyetlen olyan szereplője sem, amely valamely szinten ne függne annak zavartalan, zökkenőmentes működésétől. A közlekedés bármely alágazata (közúti, vasúti, vízi, légi, városi közlekedés), módja (pl.: egyéni, közösségi közlekedés, árufuvarozás stb.) igen összetett, sok tényező együttmüködését igénylő folyamat. A folyamatok lebonyolításában jelentkező zavarok nemcsak annak müködésében okozhatnak problémát, de hatásuk érezhető több más területen is, akár rövid, akár hosszabb távon egyaránt. A továbbiakban a közlekedési alágazatok közül a vasúti közlekedést vizsgálom részletesen.

\section{A TERRORIZMUS ÉS A VASÚT KAPCSOLATA}

Az [1], [2], [3], [4], [5] kifejti, hogy a vasúti alágazat „puha célpontként” szerepel a terrorszervezetek listáján. Ennek megértésére álljon itt [6] tanulmány, amely szerint a terrorizmus definíciójának három fö vonása:

1. „A tevékenység lényege: erőszak szándékos alkalmazása, illetve azzal történő fenyegetés. A kevesek ellen történt terrortámadásokkal relatíve könnyen el lehet érni, hogy a többség biztonság érzékelésében kedvezőtlen változások álljanak be, a politikai kormányzat, a közszféra szervezeteiben dolgozók és a polgári lakosság egyaránt elbizonytalanodjon; a társadalom politikai, társadalmi, gazdasági életében zavar keletkezzen. A megrettent polgári lakosság biztonságának újbóli visszaszerzésének reményében gyakran igyekszik rábírni az aktuális politikai hatalom képviselöit a terroristákkal való tárgyalásra, illetve politikai társadalmi gazdasági vagy vallási követeléseik legalább részleges akceptálására.

2. A tevékenység végcélja: politikai célok elérése a „puha célpontok” elleni váratlan, sokkoló szándékú, nemzetközi jog által illegitimnek tekintett és formálisan mindenképpen üldözni, büntetni rendelt, lehetőség szerint a médiában minél nagyobb "híradás értékü" támadással.

3. Célpontok: civilek, a biztonsági szektor szervezeteinek, illetve intézményeinek szolgálatban lévő, illetve szolgálaton kívüli tagjai és kiemelt, szimbolikus jelentőségünek gondolt célpontok. A terrorcselekmények tervezői a célpontok kiválasztásakor, illetve az áldozatok potenciális körének számbavételekor általában törekszenek a propagandahatás lehetőség szerinti maximalizálására (pl. olimpiai játékok; karácsony; egyéb vallási, illetve nemzeti ünnepek idejére időzített támadásaikkal).”

[3] a terrorcselekmények célpontjainak csoportosítását az alábbiak szerint javasolja:

- viszonylag kiszámítható áldozatok (politikusok, üzletemberek, közéleti személyiségek, fegyveres erők magas rangú tagjai, stb., vallási, etnikai közösségek),

- szinte teljesen véletlenszerüen kiválasztott célpontok és áldozatok.

Az áldozatok többsége általában rosszkor van rossz helyen, teljesen vétlen a támadás indítékában. Ilyen helyek lehetnek a bevásárló központok, éttermek, vásárok, kulturális és sportlétesítmények, szórakozóhelyek, múzeumok, szakrális helyek, közlekedési eszközök, turisták által kedvelt célpontok. Az említett helyek közös jellemzöje, hogy egyszerre sok ember lehet jelen (pl. közösségi közlekedési csúcsidő). Így az akciók sikere szinte garantált. Az egyre inkább radikalizálódó és eszközeikben, módszereikben egyre kevésbé válogató terrorszervezetek számára ezért is váltak a közösségi közlekedés járművei és létesítményei a támadásaik kedvelt célpontjaivá. A közlekedési szektor azok közé tartozik, amelyek könnyen támadhatók, és viszonylag kis kockázat mellett súlyos következményekkel járó akciókat lehet elkövetni [7]. 
A vasúti személyszállítás jellemzője, hogy a csúcsidőszakokban nagyon sokan használják egyszerre a vasúti szerelvényeket az elővárosi forgalomban, illetve a nagyvárosi vasútállomásokat. Így egy azok ellen elkövetett terrorakció megfelelö hatást érhet el az emberekben és az állami szerveknél. Az elkövetett cselekmény hatására, - amely nagy áldozatszámmal jár - a félelemérzet nőhet, az államba vetett bizalom megrendülhet, a kívánt cél, a káosz, illetve a destabilizáció elérhető.

\section{A VASÚTI KÖZLEKEDÉS BIZTON- SÁGA}

A vasút veszélyes üzem voltából adódóan már az üzembiztonság is megköveteli, hogy a biztonsági rendszerek többkörösek legyenek, azaz egy biztonsági rendszer meghibásodása esetén ne történjen automatikusan baleset, hanem legyen még egy rendszer, amely szavatolja az üzembiztonságot. Ez a biztonsági filozófia már önmagában képes valamiféle védelmet nyújtani a szándékosan ártó cselekmények ellen és az ehhez társuló szakmai tudás a vasútüzem biztonságát növelheti. Ebben a fejezetben ezek bemutatása történik meg.

\subsection{Vasúti biztonságfilozófia}

Azokat a lehetőségeket, amelyek a vasúti közlekedésben veszélyeztetésekhez, balesetekhez vezetnek, veszélyforrásoknak tekintjük [8]. A veszélyforrások balesethez vezető hatása elleni védelmet szolgálják:

- a különböző utasítások, szabályzatok,

- szabványok,

- technológiai elöírások,

- a különböző biztosítóberendezések,

- biztonsági berendezések (pl.: olvadó biztosíték).

A műszaki fejlődés a vasúti közlekedés biztonságát nagymértékben növeli, de egyben a korszerű technika „gyenge pontjai” veszélyforrások előidézői is. A vasúti közlekedés biztonságát döntően befolyásolják a pálya, a vontató és vontatott járművek, valamint a biztosítóberendezések konstrukciója, üzemeltetési feltételei.
A vasútüzem biztonsága az üzem területén jelentkező veszélyforrások elleni védekezés és a baleset-megelőzési munka eredményességét fejezi ki. A vasúti közlekedés biztonságát a technikai feltételek oldaláról a műszaki biztonság, az üzembiztonság és a forgalombiztonság együttesen határozza meg, amelyek építökocka-elv szerint egymásra épülnek, és szoros kapcsolatban állnak egymással:

- A müszaki biztonságot az eszközök szerkezeti részeinek konstrukciója, a technológiai tökéletessége határozza meg, mértékét a kialakításnak, a méretezésnek a veszélyhatártól mért különbsége befolyásolja.

- Az üzemi biztonság elsődlegesen a müszaki biztonságra épül, és annak eredményességét mutatja, mert a konstrukció vagy az alkalmazott technológia „gyenge pontjai” az üzemi hibákkal találkozva balesetekhez vezethetnek. Az üzemi biztonságot tehát döntően befolyásolják a közlekedés eszközeinek, berendezéseinek zavar-, illetve hibaérzékenységei, azok felügyelete, vizsgálatainak színvonala, valamint a kezelés hibái.

- A forgalombiztonság elsődlegesen az üzemi biztonságra épül, és annak eredményességét mutatja, mert az üzemi hibák a forgalmi követelményekkel találkozva balesetekhez vezethetnek. A forgalombiztonságot az utasítások rendszere, a szabályozottság foka, a közlekedésben résztvevők szabályozott együttmüködése, a szabályok ismerete és azok megtartása befolyásolja.

A forgalombiztonságot szolgáló utasításrendszer az emberi tudásra épít, amely egy nem kívánt esemény bekövetkezésekor a forgalmi teendőket meghatározza. Ez hasznos lehet olyan terrorcselekmények bekövetkezésekor, amelyek nem a járművek ellen irányulnak, hanem a pályaelemek ellen. Például a nem egyértelmü jelzések észlelésekor a forgalmi személyzet megfelelő tudás birtokában megakadályozhatja balesetek kialakulását. 


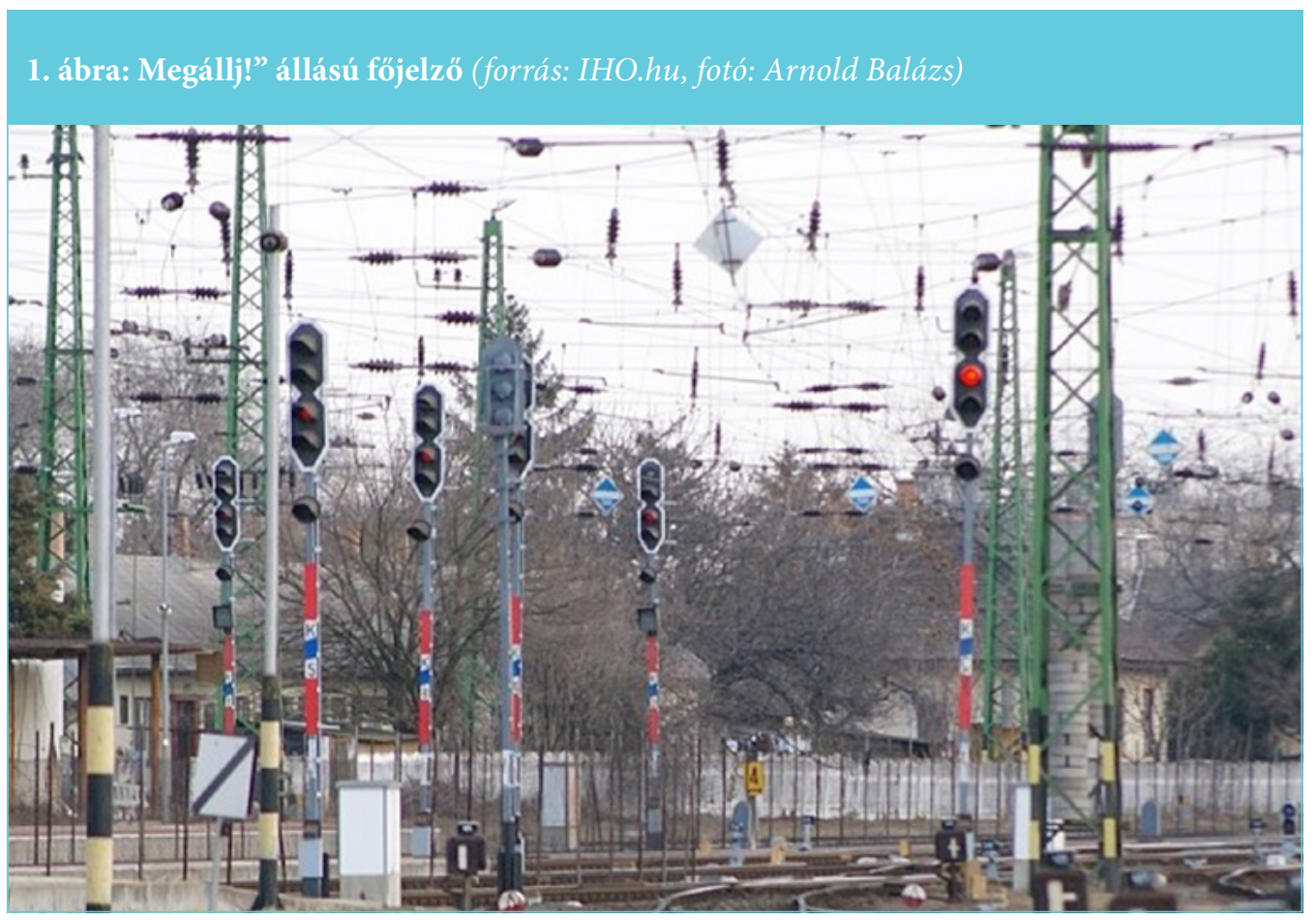

A biztosítóberendezések kialakításának és szerkesztésének főbb elvei, követelményei:

- álló jármű nem okoz balesetet, ezért alapállapotként a „Megállj!” jelzést (nagyon kevés kivételtől eltekintve) kell figyelembe venni (1. ábra), illetve a veszély esetén a jármüvek megállítására kell törekedni;

- jelző „Szabad” állásba csak akkor állítható, ha a menetben érintett váltók a helyes irányban le vannak zárva, a védőobjektumok védőállásukban rögzítettek;

- lezárt vágányút csak akkor oldható, ha a vonat a saját vágányútján végighaladt és a mögötte fedezést megvalósító jelző „Megállj!” állásban van;

- „Szabad” állású jelző bármikor és függés nélkül „Megállj!” állásba állítható;

- a berendezésben fellépő hiba nem okozhat közvetlen balesetveszélyes helyzetet;

- a biztonsági berendezésrészek egymást ellenőrzik; a nem ellenőrizhető részeknél nagy megbízhatóságú szerkezeteket kell alkalmazni;

- az üzembiztonság növelésére tartalék áramellátó rendszert kell alkalmazni.
Az álló jármű nem okoz balesetet alapelv elérése érdekében a mozgó járműveknél fellépő probléma esetén - bizonyos esetektöl eltekintve - a legfőbb teendő a jármű megállítása. $\mathrm{Az}$ alkalmazott fékrendszerek ezt segítik elö, és müszaki megoldásuk szerint a rendszer sérülése esetén a vonatot automatikusan megállítják.

Ugyancsak ezen alapelv mentén működnek az un. járműfedélzeti berendezések, amelyek feladata a mozdonyvezető éberségének ellenőrzése. A meghatározott időközönként vagy távolság megtétele után szükséges visszajelzés elmaradásakor a rendszer automatikusan megállítja a vonatot, így a mozdonyvezetővel történt probléma esetén (pl. terrorcselekmény) a szerelvény megáll, így elkerülhetők az esetleges balesetek.

A fejezet elején említett többkörös biztonsági rendszerek segíthetnek a katasztrófák elkerülésében. A „Szemed mindig a pályán legyen!” felhívás jegyében a mozdonyvezető sokat tehet a balesetek megelőzéséért. A pályamenti jelzők megfigyelése és megfelelő értelmezé- 
se (utasítás ismerete!) felkeltheti a figyelmet, hogy valami nem az elöírtak szerint történik, pl. a kitérőbe történő behaladás helyett egyenesbe történő behaladásra utaló jelzési kép jelenik meg a jelzőn, vagy a váltójelző és a főjelző jelzési képei nincsenek összhangban egymással, esetleg szabad térközre utaló jelzés esetén a vonat végét jelző vörös fény van a látótávolságban, vagy szabad állású jelző melletti elhaladás után egy vörös fény jelenik meg a vezetőállás-jelzőn.

A vasúti biztosítóberendezések alapelvei szerint hiba esetén mindig a biztonság, azaz az alacsonyabb sebesség vagy a megállás irányába változnak a parancsok (pl. zöld fény kiégése esetén sárga jelenik meg, amely egy fokkal aggályosabb jelzés a zöldnél). A mindenkori megállási parancsot adó vörös fény meglétét duplázással oldják meg, un. pótvörös áramkört építenek be, hogy az eredeti áramkör meghibásodása esetén is kivezérlehető legyen vörös fény a jelzöre (ennek külön izzója is van).

Abban az esetben, ha a terroristák magát a továbbhaladást megtiltó jelzést semmisítik meg, akkor a rendszer olyan elöjelzést ad, hogy már az előző térközt is foglaltnak tekinti, így az előző főjelzőn vörös fény jelenik meg, illetve továbbhaladást engedélyező jelzési kép nem vezérelhető ki (sötét jelzőre vörös fény ad „előjelzést”). Egyebekben a forgalmi és jelzési utasítások részletezik, hogy sötét jelző mellett milyen elhaladási szabályok érvényesek.

\subsection{Vonatbefolyásolás}

Ez alatt azt a folyamatot értjük, amely során a haladó vonat mozdonyvezetője közvetlenül a vezetőálláson a jelzők jelzési képétől és az engedélyezett sebességtől függően információkat kap, s ha ezeknek megfelelően a vontatójármü személyzete nem vagy csak késve avatkozik be, figyelmeztetés után a vezérlés megszünteti a vontatójármű vonóerő-kifejtését, és kényszerfékezést indít meg [9]. Megvalósítása kétféleképpen lehetséges:

- pontszerü (adott jelző mellé telepítik, öszszefüggésben van a jelző müködésével),
- folyamatos (az információ folyamatosan érkezik a vontatójármüre, így a jelzési képben bekövetkező bármilyen változás azonnal megjelenik a vontatójárművön).

A vonatbefolyásolási rendszer jármüre szerelt berendezésének feladata a következő:

- a vonatbefolyásolásra kiépített vonalszakaszokon betölti az ismétlőjelző szerepét (mutatja, hogy az előtte levő jelzőn milyen jelzés van), illetve a fékberendezés müködés-vezérlését, valamint időszakos éberségellenőrzést (a mozdonyvezető figyelmét, cselekvőképességét ellenőrzi: amennyiben megállapítja a cselekvőképesség elvesztését, befékezi a vonatot) biztosít;

- a vonatbefolyásolásra ki nem épített vonalszakaszokon időszakos éberségellenőrzést biztosít.

A vasutak vontatójármüvein az éberségi berendezések különböző változatai találhatók, a pusztán jelenlétet ellenőrző berendezéstől kezdve, az éberségi berendezésen keresztül a korszerü, önműködő egyesített éberségi és vonatbefolyásoló berendezésig. A vonatforgalom biztonságának további növelése a helyhez kötött biztosítóberendezés üzembiztonságának fokozása mellett csak az információátviteli rendszerben megvalósítandó automatizálás útján lehetséges anélkül, hogy az emberi tényező feleslegessé válna.

A hagyományos nagyvasúti közlekedés biztonságát az állomási és vonali biztosítóberendezések megfelelő működése jelenti. Elmondható azonban, hogy ez csak akkor ad kellő védelmet, ha a mozdonyvezető a - pálya mellett elhelyezett jelzők által meghatározott - sebességparancsokat hibátlanul értelmezi és maradéktalanul betartja. A helyhezkötött pályaberendezések (biztosítóberendezés) és a mozdony berendezései (pl. fékberendezés) közötti információs láncba tehát beékelődött az ember. Ezért a legkorszerűbb állomási és vonali automatikáknál az emberi tényező (mozdonyvezető) szerepe továbbra is nagy jelentőségü. Mindemellett a jelzések megfigyelésének (értelmezésének) különböző nehézségei lehetnek: 
- a nagyobb sebesség miatt egyre kisebb időközben érkeznek jelzési parancsok, amelyek korrekt megfigyelésének és pontos kiértékelésének valószínűsége csökken,

- a távolbalátás korlátozottsága (pl: sürü köd),

- a mozdonyvezető fiziológiai és lélektani kondíciójának hiányosságai (pl. figyelmetlenség, befolyásoltság),

- egyéb, a jelzők megfigyelését nehezítő, vagy elterelö külső vagy belső körülmények.

Amennyiben a mozdonyvezető nem veszi figyelembe a "Megállj" állású jelző utasítását, akkor a vonatbefolyásoló berendezés müködésbe lép.

\subsection{Vasútirányítási rendszerek}

A vasút rohamos térnyerésével együtt a vasúti közlekedés sebességével és biztonságával szemben támasztott elvárások egyre szigorúbbak lettek, s szükségessé tették olyan berendezések kiépítését, amelyek alkalmasak a vonatközlekedést irányító jelzések, esetleg egyéb információk (pl. sorompók állapotának) jármüre történő nagybiztonságú eljuttatására. $\mathrm{Az}$ igazi áttörést (elvárt színvonalat) a többfogalmú jelfeladás (hazai elektronikus vonatmegállító [EVM] rendszer) elterjedése hozta meg a vonatbefolyásolás fejlödése során.

A vasúti közlekedés irányításának területén az egyes európai országokban különbségek vannak, amelyek föbb okai [9]:

- a jelzési rendszerek eltérősége,

- a jelzö-, biztosító- és távközlőberendezések sokfélesége,

- különböző szakmai felkészültségü, eltérő tudásanyaggal és nyelvismerettel rendelkező személyzet,

- az infrastruktúra (pl. áramrendszer) és a vontató jármüpark müszaki jellemzőinek jelentős eltérése miatt szükséges mozdonycserék.

A fentiek miatt a vasúti közlekedés folyamatosságának biztosítása akadályokba ütközött. A probléma megoldására különböző kiegészí- tő eszközöket fejlesztettek ki, amelyek azonban nagyon költségesek. A különbözöségek megszüntetésére az Európai Unió Tanácsa 1996 júliusában fogadta el a 96/48/EK irányelvet a nagysebességű transzeurópai vasúti rendszer kölcsönös átjárhatóságáról. Az irányelvben definiálták az átjárhatóság fogalmát, célját, szerepét, jelentőségét, alapvető követelményeit, megvalósításának elveit, feltételeit, módját, műszaki előírásait, továbbá egyéb, az előzőekkel összefüggő értelmezéseket és eljárásokat tartalmaznak.

A vasútirányítási rendszerek különbözőségének kiküszöbölésére egy olyan rendszert fejlesztettek ki, amely a jogi, müszaki és piaci nehézségeket egymaga is sikerrel kezelte. Ez az új rendszer az Egységes Európai Vasútirányítási Rendszer (European Rail Traffic Management System [ERTMS]).

Az ERTMS mint rendszer három területre terjed ki:

1. European Traffic Management Layer (ETML) - Európai Közlekedésirányítási Szint - forgalomirányítási terület (2. ábra)

2. European Integrated Railway Radio Enhanced Network (EIRENE) - Egységes Európai Vasúti Rádióhálózat - kommunikációs terület (3. ábra)

3. European Train Control System (ETCS) Egységes Európai Vonatbefolyásoló Rendszer - forgalombiztonsági terület (4. ábra).
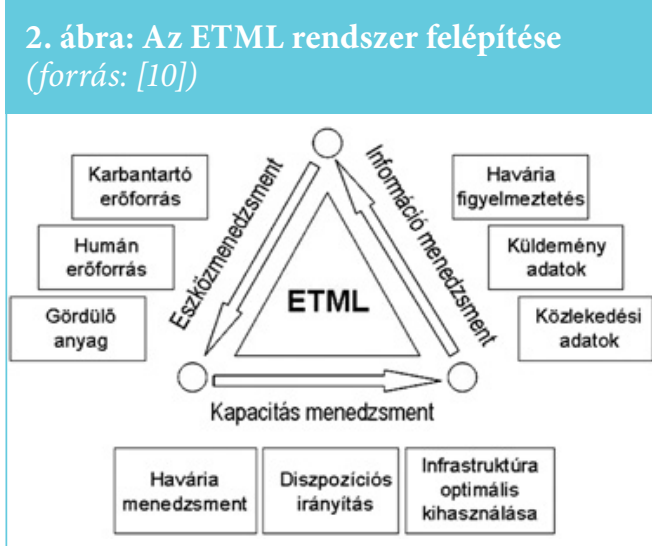


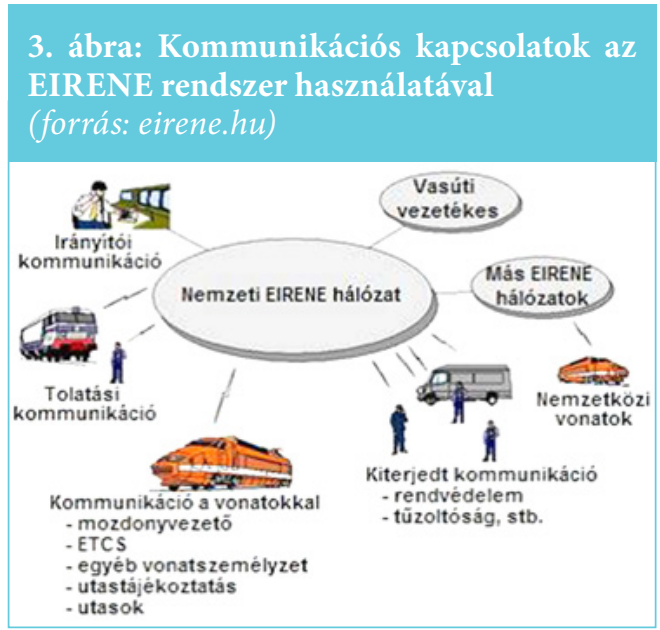

Az ERTMS főbb tulajdonságai [11]:

- európai interoperabilitás,

- magasabb biztonsági és szolgáltatási színvonal,

- a legújabb szabványoknak való megfelelés, a nemzetközi együttmüködés és a pontos specifikációk a biztonság növelését szolgálják,

- nagy megbízhatóság és biztonságos müködés,

- megemelkedett szolgáltatási színvonal,

- automatizáltság a sebességvezérlés és -felügyelet területén,

- növelhető sebesség és vonalkapacitás, jobb infrastruktúra-kihasználás,
- GSM-R alapú adatátvitel,

- igény szerinti bevezetési megoldások alakíthatók ki a jelenlegi vonatbefolyásoló rendszerről az ETCS-re való átálláskor (migráció).

$\mathrm{Az}$ említett rendszereket mind-mind azért fejlesztették ki, hogy a legnagyobb (biztonsági) kockázatot jelentő ember szerepét tovább csökkentsék, így az üzembiztonságot tovább növeljék. Az ERTMS rendszer bevezetésével a vasúti közlekedés európai szintü irányítása egységessé válik. Ugyanakkor az egyre több informatikai (távvezérlési) megoldás miatt ezek a rendszerek a kiberterrorizmus célpontjaivá is válhatnak.

\section{VASÚTI KIBERTERRORIZMUS}

A vasúti pályák és szerelvények mellett a harmadik nagy célpont lehet a vasúti irányítóközpontok elleni támadás. Itt elsősorban nem magának az épületnek a hatalomba kerítéséről van szó, hanem az itt müködő informatikai rendszerek elleni támadásról, azaz a kiberterrorizmusról. Ebben az esetben a cél az olyan rendszerek elleni támadás, amelyek közvetlenül irányítanak vasúti forgalmi rendszereket. A vasúti irányítóközpontok számítógépes rendszere állomások, egész vonalak, vonalhálózatok közlekedését irányítják és felügyelik, az ellenük intézett támadás sok ember életét veszélyezteti. Az

\section{4. ábra: Az ETCS kapcsolódási felületek (forrás: [12]) \\ rövidítések: RBC - radio block center (rádió blokk központ); TRM - MSC - Kapcsolóközpont; BSC - Bázisállomás vezérlö; BTS - Bázisállomás;}

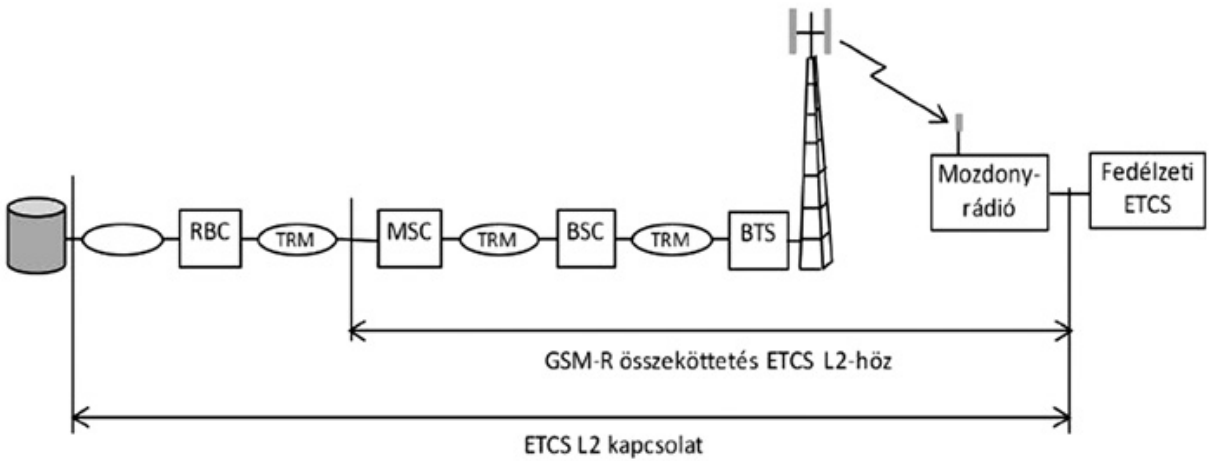


irányítóközpontok munkájában a felügyelet jelenti a kisebb gondot, hiszen ekkor csak az állomáson dolgozók munkájának ellenőrzése történik a központból, a tényleges forgalomszabályozás az állomásokon valósul meg. A jelentősebb problémát a központi forgalomirányítás jelenti. A forgalomirányító rendszert ért kibertámadás okozhat olyan szituációt (pl. vágány foglaltságérzékelésének megszüntetése, kitérők végállásának virtuális megváltoztatása), amelynek következménye súlyos, jelentős áldozatszámmal járó baleset bekövetkezése lehet.

A vasútállomások (hagyományos) biztosítóberendezései elleni támadás nem sorolható a kibertámadás kategóriába, mert a legtöbb vasútállomás esetében távolról nem lehetséges a rendszer elérése, azt csak helyben lehet végrehajtani. Villamos úton függésbe hozott jelzők és kitérök közötti jelfogóáramkörök megváltoztatásához speciális felkészültség szükségeltetik, nem elég az informatikai tudás a direkt károkozáshoz.

Modern, számítógép által vezérelt állomási biztosítóberendezés esetén már elképzelhető a rendszer elleni kibertámadás. Szinte minden vasútállomás rendelkezik internet hozzáféréssel, így az állomás biztosítóberendezési rendszere (elvileg) távolról is elérhető. Ebben az esetben a távolról történő rosszindulatú beavatkozás már képes emberáldozatokkal járó baleset előidézésére (pl. váltó végállásellenőrzésének kiiktatása révén).

A vonali biztosítóberendezések üzemének szándékos megzavarása lehetséges lenne, de ezek az áramkörök a vonaton keresztül záródnak, így a ténylegesen foglalt térköz előtti térközjelző továbbhaladást engedélyező jelzési képének eléréséhez a vonatot kellene valahogy eltüntetni a térközből. A „hamisfoglaltság” a biztonság irányába történő tévedés.

A biztonságfilozófiából és a vasúti személyzet ismeretéből következően a nem megfelelően működő biztosítóberendezések által okozott problémák kiküszöbölhetők. Az igazi nehézséget a vezető nélküli vasúti közlekedés jelenti (pl. M4 metró). Ebben az esetben a teljes forgalomirányítást és lebonyolítást számítógép végzi, így a rendszer elleni támadás súlyos balesethez vezethet (pl. egy szerelvény belerohan az állomáson álló másik szerelvénybe). Nagyon fontos tehát a vasúti informatikai rendszerek megfelelő védelme a külső behatolás ellen.

Ugyancsak problémaként jelentkezik az esetleges kibertámadások során az áruszállítási informatikai adatok megszerzése. A veszélyes árukat szállító vonatok közlekedési adatainak megszerzése elősegítheti az ilyen vonatok ellen tervezett akciókat. Erre mutat rá a közlekedési informatikai rendszerek sérülékenységéről írt tanulmány [13]. Ez esetben az akció nem a vonat ellen irányul, hanem csak az adatok megszerzése a cél. A vonat közlekedési adatainak birtokában (menetrend, szállított veszélyes áruk, stb.) lehet a tényleges fizikai terrortámadást megszervezni. Ezért fontos az árufuvarozási informatikai rendszerek megfelelő védelme.

\section{PÉLDÁK A VASÚTI TERRORIZ- MUSRA}

\section{A madridi példa}

Madridban 2004. március 11-én történt terrortámadás a városba vezető elővárosi vasúthálózaton, illetve az Atocha pályaudvar és két kisebb állomás közvetlen közelében. Az akció 192 halálos áldozatot követelt, a sérültek száma több mint 1400 volt. Az időpont kiválasztása nem volt véletlenszerü, pontosan két és fél évvel a 2001. szeptember 11-i, New York-i után és pár nappal a spanyol választások elött (március 14.) történt a támadás (5. ábra).

Ez a terrorakció megmutatta, hogy a nemzetközi terrorista csoportok képesek egy nyugat-európai fóvárosban is összehangolt támadást intézni, és súlyos veszteséget okozni emberéletben, közlekedési eszközökben egyaránt.

A terrortámadás tapasztalatait és hátterét [5] foglalja össze. 


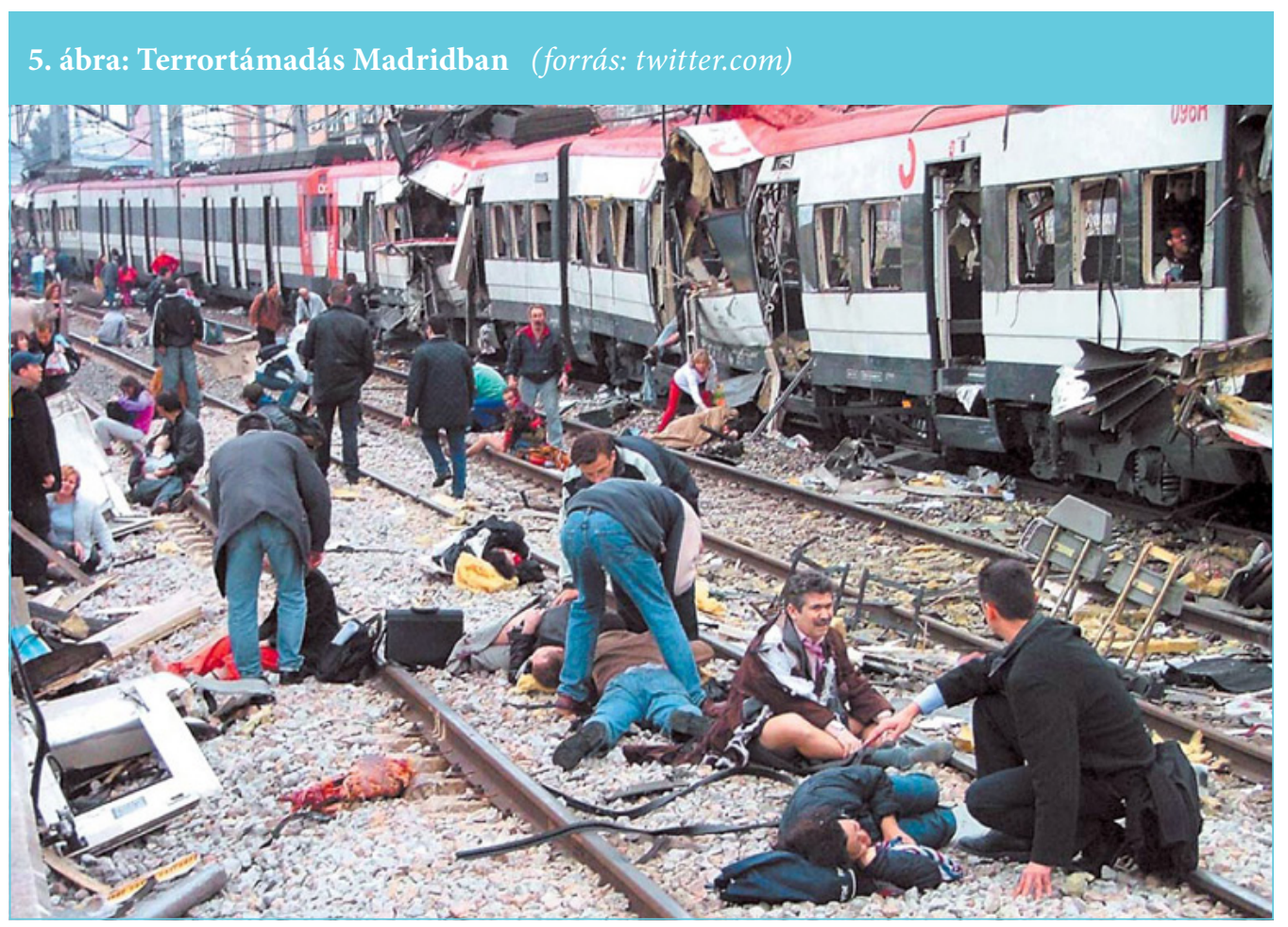

\section{A londoni példa}

A londoni metrót 2005. július 7-én érte terrortámadás. Az elkövetők metrókocsikban robbantottak. Az akciónak 56 halálos áldozata és több mint 700 sérültje volt. A robbanások az alagútban következtek be, ahol a szűk tér tovább fokozta a metrókocsikban utazók halálának lehetőségét, mivel a törmelékdaraboknak nem volt hova szétszóródniuk. Ebből is látszik, hogy az akció célja a minél több áldozat és sérült elérése volt. A szűk tér miatti nagyobb hatás elérhetőségének érdekében a földalatti szerelvények még inkább kedvezőbb célpontjai lehetnek terrorakcióknak. Az időpont megválasztása itt sem volt véletlen. A Skóciában pont ekkor rendezett G8-as csúcstalálkozó megfelelő apropót adott az akció végrehajtásához.

Az akció hátterét [14] elemzi.

A Csatorna-alagútban közlekedő vonatok esetében is ezért vezették be a repülőtérihez hasonló biztonsági ellenőrzéseket.
Orosz példák [15], [16]

- 2004. február: a moszkvai metróban történt öngyilkos robbantás, 41 halálos áldozattal,

- 2007. Nyevszkíj-expressz felrobbantása a Moszkva - Szentpétervár vasútvonalon, 60 sérült, halálos áldozat nem volt,

- 2009. november 29.: a Nyevszkíj-expressz felrobbantása, itt már 26 áldozattal, 81 sérülttel,

- 2010. március 29.: robbantás a moszkvai metróban, 40 halálos áldozat, több mint 90 sérült,

- 2011. április 11. Minszkben (Fehéroroszország) robbantottak a metróban, 13 halálos áldozat, 161 sérült,

- 2017. robbantás a szentpétervári metróban, 14 halálos áldozat, legalább 40 sérült.

\section{A Thalys példa [17]}

Ugyan nem az infrastruktúra elleni támadás, hanem a vonat utasai elleni akció volt, de 
mindenképpen idetartozik az Amszterdamból Párizsba tartó Thalys nagysebességü vonaton 2015. augusztus 21-én elkövetett merénylet. A támadó számos fegyvert (géppuska, kések) vitt fel a vonat fedélzetére azzal a céllal, hogy támadást intézzen az utasok ellen. Ezt a tervet az utasok megakadályozták és csak sérülések érték őket a férfi lefegyverzése közben. Ehhez persze szerencse is kellett. Azzal, hogy utaztak olyan katonák a járaton, akik felismerték a fegyvertöltés hangját, és azonnal tudtak reagálni a helyzetre. Sikeres terrorakció esetén, menekülési lehetőség híján az áldozatok száma jelentős lehetett volna.

A támadás arra világított rá, hogy megoldatlan a vasúti szektorban az utasok poggyászának ellenőrzése, ezért fegyverek is ellenőrzés nélkül vihetők fel a vonatok fedélzetére.

\section{KRITIKUS VASÚTI INFRA- STRUKTÚRA ELEMEK}

A vasúti infrastruktúrának minden országban számtalan eleme van. Az teljesen természetes, hogy a hálózat összes elemét nem lehetséges és nem is kell kritikus infrastruktúra elemnek tekinteni. Éppen ezért az első kérdés annak tisztázása, hogy egy adott alágazatban mit lehet a kritikus infrastruktúra részének tekinteni. Ehhez azonosítani kell az alágazat elemeit. A terrorizmus elterjedése óta a kritikus infrastruktúrák esetében lehetséges kockázatok számbavételének és elemzésének módja bővült [18]. A kockázatok meghatározásánál figyelembe kell venni a fenyegetettséget, az adott rendszerelem sérülékenységének öszszetevőit, valamint a rendkívüli események esetleges bekövetkezésének várható következményeit.

2005 novemberében az Európai Bizottság ún. Zöld Könyvet fogadott el a létfontosságú infrastruktúrák védelmére vonatkozó európai programról (EPCIP) [19]. A védelmi szféra szakértőinek vezetésével 2007-ben kezdődött meg a hazai Zöld Könyv elkészítése az uniós minta alapján, az ország veszélyeztetettségének felmérését követően. A Zöld Könyv meghatározta a közösségi és nemzeti szin- tű kritikus infrastruktúrák azonosításának és közösségi együttműködésének alapelveit.

A közlekedés kritikus infrastruktúra elemeinek azonosításánál célszerű a technológiaitechnikai és földrajzi tényezőkből kiindulni [2]. A technológiai-technikai vizsgálat választ adhat a vasúti rendszer jármüveinek és létesítményeinek állapotából, korából fakadó teljesítőképességi korlátokra, az esetlegesen bekövetkező rendkívüli események helyére. A földrajzi tényezőket kétfelé bontva érdemes vizsgálni. A természetföldrajzi szempontok meghatározása választ adhat olyan kérdésre, hogy egy adott területen milyen természeti kockázati tényezőkkel kell számolni (pl. árvíz), illetve leszűkítheti a természeti kockázati tényezők körét, és választ adhat az esetleges rendkívüli események bekövetkezésének térbeni és időbeni kiterjedésére. A társadalomés közlekedésföldrajzi tényezők számbavétele komoly segítséget nyújt a közlekedési szektor horizontális és ágazati kritériumainak meghatározásában.

A fizikai és emberi kockázatok mellett a kritikus infrastruktúra elemek meghatározásakor fontos figyelembe venni az esetleges kibertámadások fenyegetéseit is. Erről korábban már szó volt, itt csak megemlítem, mint szükséges kockázati elemet. A közlekedési szektor függősége a telekommunikációs, informatikai irányítási rendszertől már olyan mértéket ért el, hogy kiterjedt, súlyosabb következményekkel járó rendkívüli eseményeket lehet elérni ezeknek a rendszereknek a zavarásával. A [20] is megfogalmazza, hogy a kritikus infrastruktúra halmaza kiegészül azokkal az informatikai rendszerekkel, hálózatokkal, eszközökkel és folyamatokkal, amelyek egy-egy kritikus infrastruktúra működését informatikai, technikai, technológiai vagy távközlési szempontból támogatják.

A fentiek alapján, általánosságban, a közlekedési rendszer kritikus pontjainak tekinthetjük:

- a közlekedési alágazatok termináljait: vasúti pályaudvarok, autóbusz-pályaudvarok, repülőterek, kikötők, metróállo- 
mások, a személyszállítás és a kombinált árufuvarozás csomóponti állomásait,

- a forgalmi csomópontokat, határátkelöhelyeket, a közlekedési alágazatok csatlakozási pontjait,

- a közlekedési alágazatok pályáinak mütárgyait, úm. alagutak, hidak, felül- és aluljárók, váltóberendezések, üzemanyag- és energiaellátási rendszerek.

Szinte valamennyi állami és közösségi felfogás abból indul ki, hogy a kritikus infrastruktúrák közé azokat az elemeket és alrendszereket lehet besorolni, amelyeknek valamilyen rendkívüli eseményhez kapcsolható kiesése emberi életek elvesztésével járhat, gazdasági hátrányokat és anyagi károkat, valamint fennakadásokat okozhat a társadalom mindennapjaiban és a közigazgatásban.

Az általános meghatározás után nézzük a vasúti alágazat elemeit.

A [21], [22] már definiálta a kritikus vasúti infrastruktúra fogalmát, ami alapján az alágazat infrastruktúrája alapvetően a következő elemekből épül fel:

1. vasútállomások (beleértve minden, egy állomáson megtalálható építményt is, pl. vontatási telep)

2. a vasútállomások közötti nyíltvonal (két szomszédos állomás bejárati jelzője közötti vágányszakasz)

3. saját célú vasúti pályahálózat (iparvágányok)

4. a vasút müködését biztosító egyéb infrastruktúra (pl. villamos alállomás)

A vasútállomások tekintetében az állomások egyes elemei (pl. vágányok, kitérők, gurítódomb) nem tekinthetök külön-külön kritikus infrastruktúra elemnek, mert az egyes elem megsemmisülése nem teszi az adott állomást használhatatlanná. Általában azt lehet rögzíteni, hogy magának az állomásnak vagy csomópontnak a kiiktatása jelent problémát, ezért az egész állomást tekintjük a kritikus infrastruktúra elemének (pl. budapesti fejpályaudvarok).
A vasúti pályáknak, mint közlekedési infrastruktúrának vannak olyan pontjai, amelyek megsemmisülése vagy megrongálódása jelentős károkat okoz az ország életében. Magyarországon ilyenek a jelentős nagyfolyami hidak (pl. Déli összekötő híd, Szolnok - Szajol Tiszahíd), alagutak (pl. Kelenföld - Déli pályaudvar közötti alagút), illetve egyes állomásközök, ahol a vasúti pálya megrongálása jelentős forgalmi korlátozással járhat, mert a vasúti pálya átbocsátóképessége nagyon-nagy mértékben lecsökkenhet vagy akár meg is szünhet.

A saját célú pályahálózat esetén olyan iparvágányok elleni akciókról beszélhetünk, amelyek adott üzem munkáját béníthatják meg, amennyiben a müködéshez szükséges anyagokat vasúton szállítják a telephelyre, illetve a termékek elszállítása vasúton történik (nem áll rendelkezésre végtelen kapacitású tároló).

$\mathrm{Az}$ egyéb infrastruktúra elleni támadások ugyan kárt tehetnek a vasúti infrastruktúrában, de a forgalom lebonyolítását meggátolni nem tudják (pl. alállomás kiiktatása esetén a forgalom dízelmozdonyokkal részben továbbra is fenntartható).

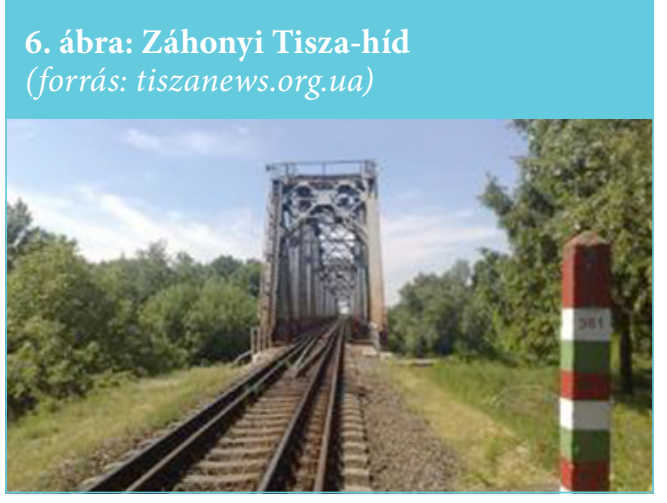

Fentiek alapján a vasúti kritikus infrastruktúra magyarországi elemei az alábbiak:

- budapesti fejpályaudvarok,

- Déli összekötő híd,

- Szolnok - Szajol Tisza-híd,

- záhonyi Tisza-híd (6. ábra),

- Kelenföld - Budapest-Déli állomásköz (alagút),

- TEN-T vasúti folyosók, 
- Kelenföld, Ferencváros, Szolnok, Székesfehérvár, Győr, Debrecen, Miskolc, Hatvan vasúti csomópontok

- Rákospalota-Újpest, Kőbánya-Kispest, Rákos állomások,

- paksi atomerőmű saját célú vasúti pályahálózata,

- Dunai Kőolajfinomító saját célú vágányhálózata,

- villamos alállomások.

\section{A KOCKÁZATI KIHÍVÁSOKRA ADHATÓ VÁLASZOK}

A bevezetőben említett tömegszerüség miatt a vasúti szerelvények (személy- és tehervonatok egyaránt), valamint pályaudvarok megfelelö célpontjai lehetnek terrortámadásoknak. Az áldozatok valószínüsíthetően magas száma késztetheti a terroristákat ezen célpontok elleni akciókra. A védekezés ezek ellen nagyon nehézkes, ugyanis a tömeges utasszámból adódóan az egyes utasok tételes ellenőrzése lehetetlen, olyan mértékben növelné a bejutási időt, hogy az elviselhetetlenné tenné a vonattal utazást.

A személyvonati közlekedés terrorizmus elleni biztonságossá tétele és az utazás időtartama között szoros összefüggés áll fenn.

Főként az elővárosi vonalak esetében jelentkezik igény a sürü vonatkövetésre, hogy a várakozással és utazással eltöltött idő a lehető legkevesebb legyen. Ebbe nem fér bele egy 10-15 perces poggyászátvizsgálás és egy utasátvilágítás, mert az ehhez szükséges időt az utas abszolút negatív elemként értékeli a vasúti utazás során. Legfeljebb az érhető el, hogy egy megállás nélküli detektoros kapun való áthaladás legyen az ellenőrzés egy elővárosi állomáson. Természetesen a kamerák jelenléte mind az állomásokon mind a jármüveken ma már megszokott jelenség.

A távolsági forgalomban már más a helyzet. Az utazással töltött idő növekedése már elviselhetőbbé teheti egy további ellenőrzési fázis beiktatását. Ebben az esetben a szükséges 1015 perc nem nagy többletidő a teljes utazási időhöz viszonyítva. Ez az időtöbblet a biztonságérzet fokozásának ára.
Az teljesen természetes, hogy Európában vasútállomásból sokkal több van, mint repülőtérből, a vonatok nem pont-pont összeköttetést kínálnak, mint a repülők, több helyen megállnak, így a biztonsági berendezések telepítésére sokkal több helyen lenne szükség.

A vonatok megállását az utasigények határozzák meg, egy vonat elégséges kihasználtságáról akkor lehet beszélni, ha az az útja folyamán majd minden megállás között megfelelően tele van. Fontos a megfelelö összhang a megállások száma és az utazási idő között, mert a sok megállás megnöveli az eljutási időt, ezt pedig az utasok nem tolerálják. A megfelelő biztonsági szint eléréséhez viszont valamennyi személyszállító vonat valamennyi megállási helyén telepíteni kellene kapukat és csomagvizsgáló berendezéseket. A vasút külön sajátossága, hogy olyan helyeken is megáll, ahol vasúti személyzet nem teljesít szolgálatot. Ezeken a megállóhelyeken teljes egészében az utasokra lenne bízva az ellenőrzés végrehajtása (önellenőrzés), ami nem várható el.

Az előzőek konklúziójakét kimondható, hogy a vasúti közlekedésnek mindig lesznek olyan pontjai, ahol az utasok teljes biztonsága nem garantálható, azonban az alábbi megoldások képesek lehetnek a terrorakciók visszaszorítására és a megfelelö biztonságérzet kialakítására.

\subsection{Beléptetőkapuk telepítése}

A vasutak esetében csak egyes nagysebességü és nagy jelentőségű vonatok esetében alkalmaznak tételes csomagellenőrzést és detektoros kapukat. Ilyen a Csatorna-alagútban közlekedő Eurostar vonat. Az ellenőrzési procedúra $\mathrm{kb}$. fél órát vesz igénybe, ennyivel nő meg az utazás időtartama.

Általában a beléptetőkapuk az utazási jogosultság ellenőrzésére szolgálnak, ugyanakkor a kapun való áthaladás ideje alatt van lehetőség az utasok ellenőrzésére is. Átlagosan egy kapu átbocsátóképessége a gyártók adatai alapján 40 utas/perc, ami 1,5 másodperc áthaladási időt jelent [23]. A detektoros kapuk képesek ennyi idő alatt jelezni a fémtárgyakat, ugyanakkor a repülőtereken alkalmazott módszer nem al- 
kalmazható (fémtárgyak elhelyezése külön dobozban). Az utasok döntő többsége visel valamilyen fémtárgyat (pl. férfiak: nadrágszíjcsat, nők: ékszerek), ezen kívül a mindenkinél lévő mobiltelefon is bezavarhat a rendszerbe. Ezért szükséges az utasok és kézipoggyászuk átvilágítása, hogy a veszélyes tárgyak (lőfegyver, kések, bombák, stb.) feltünjenek. Olyan megoldást kell találni, amely a fenti 1,5 másodperc alatt képes a feladat elvégzésre (7. ábra).

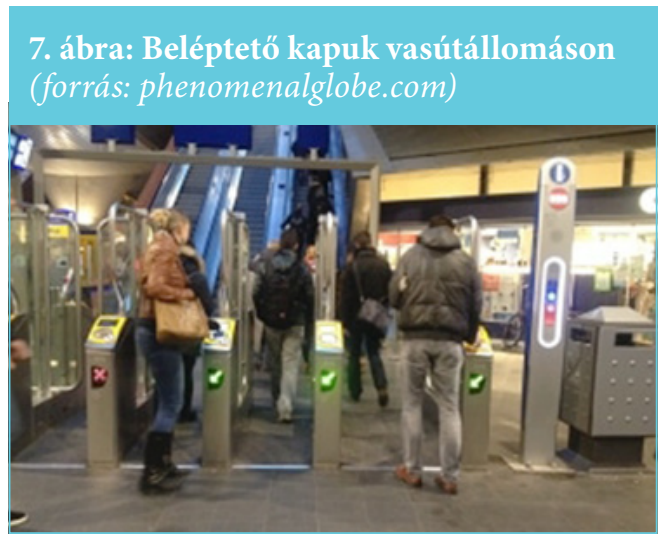

A kulcskérdés az ellenőrzés lefolytatása. Egy forgalmasabb vasútállomáson egyszerre akár tíznél is több kapunak kell üzemelnie, hogy ne keletkezzen torlódás a bejáratoknál. Ez azt jelenti, hogy egy perc alatt akár 200 utas ellenőrzését kell elvégezni. Erre nem lehet elegendő kezelőszemélyzetet alkalmazni. Megoldás lehet olyan rendszer alkalmazása, amely már önállóan képes bizonyos fegyverek felismerésére, de ez sem nyújt teljes biztonságot a rejtett bombák ellen. A rendszernek képesnek kell lenni a biztonsági személyzet riasztására fegyverfelismerés esetén, akiknek azonnal oda kell érniük, ahol a terrorista tartózkodik (pl. peron), hogy hatástalanítani tudják, mielőtt megkezdené a tervezett akciót. Ez azt jelentené, hogy minden vasúti megállóban szükség lenne biztonsági személyzetre, ami majdnem megoldhatatlan feladat. Fontos, hogy a vonaton tartózkodók védelme - a kamerák által felismert terroristák esetében - úgy is megvalósulhat, hogy az adott vonat, amire fel akar szállni, áthalad (nem áll meg) az adott állomáson. Lehetséges megoldás arcfelismerő kamerák telepítése és a nemzetközileg ismert vagy körözött személyek adatainak betáplálása a rendszerbe. Szükséges továbbá az állomások bekamerázása is, hogy az utasok és a terroristák útja követhető legyen.

A beléptetőkapuk jelenléte növelheti az utasok biztonságérzetét, hiszen azok képesek lehetnek a terrorakciók megakadályozására, vagy legalább visszatarthatják a terroristákat az akciók végrehajtásától.

\subsection{Csomagellenőrzés}

Az Eurostar vonatoknál már alkalmazzák a csomagok tényleges átvilágítását a repülőtereken alkalmazott módszerrel megegyezően. Mint korábban említettem, ez a megoldás csak távolsági utazás során jöhet szóba, ahol az utasok 15-30 perccel korábban kimennek az adott vonathoz. Manapság, az on-line jegyek világában a pályaudvar már csak a vonatra szállás helyszíneként szolgál, egyéb funkciói (várakozás, jegyvásárlás, catering) csökkennek. Így a csomagvizsgálat ténylegesen az utazási időt hosszabbítja meg, nem pedig a várakozási időből vesz el.

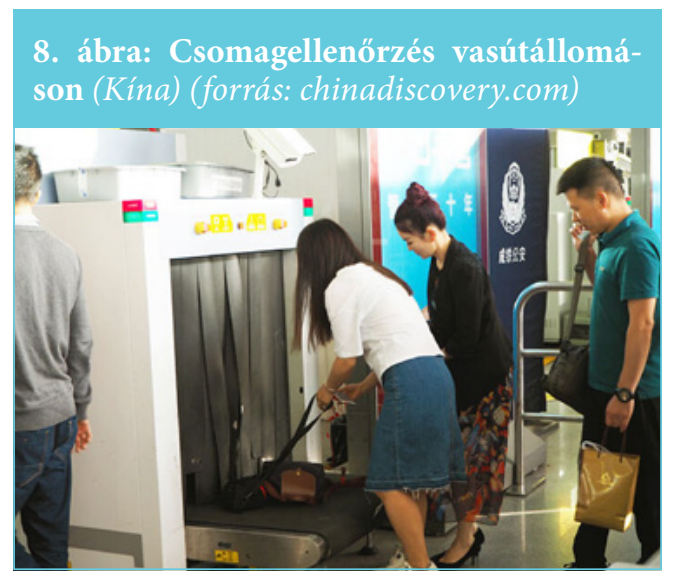

Tételes csomagvizsgálat esetén (8. ábra) egyegy frekventált vonat indulása előtt a nagyobb vasútállomásokon sor alakulhat ki, ha a vonathoz érkező utasok száma nagyobb, mint a telepített berendezések kapacitása. Ebben az esetben a várakozási idő bőven meghaladhatja a még tolerálható mértéket, ez pedig utasszám csökkenéshez vezethet. Fontos lehet megtalál- 
ni az egyensúlyt a még elviselhető mértékű várakozás és a telepítendő vizsgálóberendezések száma között.

$200 \mathrm{~km} / \mathrm{h}$ feletti sebességgel közlekedő vonatok esetében ajánlott a csomagellenőrzés, ugyanis a nagy sebesség miatt a kisiklatott vonat esetében az áldozatok száma tömeges lehet. Itt is igaz, ami a beléptetőkapuknál: az ellenőrzés növelheti az utasok biztonságérzetét, vagy visszatarthatja a terroristákat akcióik végrehajtásától.

\subsection{Fedélzeti ellenőrzés}

A vonatok fedélzetének ellenőrzése történhet kamerán keresztül, illetve a fedélzeten szolgálatot teljesítő biztonsági személyzettel (vasútőrség, rendőrség) (9. ábra).

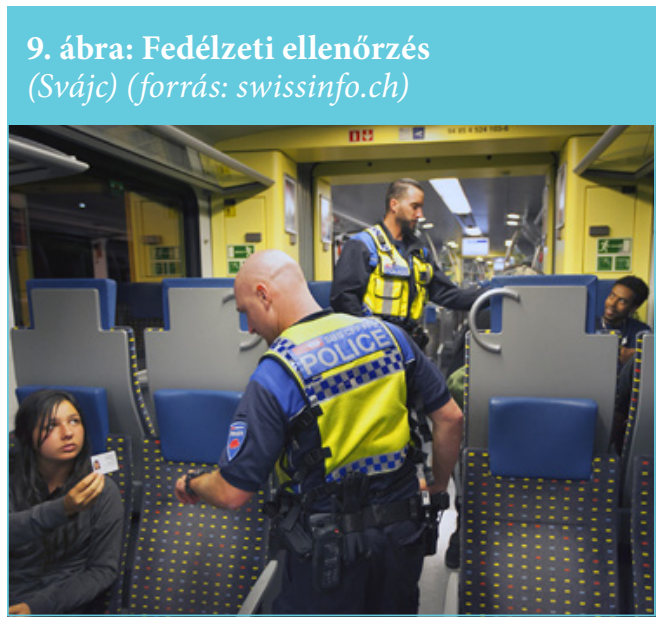

Ma már a legtöbb vasúti kocsit biztonsági kamerával szerelik fel, ami lehetővé teszi az út alatt felvételek készítését. Eredmény akkor érhető el, ha nem videó rögzítés történik, hanem „élö közvetítés” a vonatútról. A képrögzítés csak az események utólagos rekonstruálásában segít, megelőző szerepe és visszatartó ereje a terrorizmus ellen nincs, kisebb büncselekményeket, pl. lopás, azonban megakadályozhat. Miután a fanatikus terroristák ilyen esetekben általában az öngyilkos akciót választják, szinte mindegy is, hogy felismerik-e őket a rögzített képen, már amennyiben a rögzített anyag a detonációban nem semmisül meg.
Azonnali cselekvést csak a folyamatos megfigyelés válthat ki, de itt is ugyanazok a kérdések fogalmazódnak meg, mint a beléptetőkapuk esetében. Minden vonaton szolgálatot teljesítő biztonsági személyzet alkalmazása nem megoldott, ahogy a vonatszemélyzet védelmi célú felkészítése is problémás. További morális kérdésként vetődik fel, hogy elvárható-e egy vasúti munkavállalótól, hogy élete kockáztatásával védje meg az utasokat az esetleges támadásoktól.

A repülőgépek esetében az USA-ban, illetve a transzkontinentális járatokon ún. légimarsallok utaznak a fedélzeten, bár hatékonyságukat már régebben is több kritika érte [24]. A naponta közlekedö több ezer személyvonat ilyen fajta biztosítása elképzelhetetlen.

További adatvédelmi és személyiségi jogi kérdéseket vet fel az utasok állandó és folyamatos megfigyelése és kriminalizálása. Egy betegség miatt a szokásosnál többet a mellékhelyiségbe járó utas gyanússá válhat, és igazoltathatják, amely számára kellemetlen lehet. Ugyancsak kellemetlen, hogy az ember minden lépését megfigyelik az egész utazása során a kiindulási állomásra való belépésétől a célállomás elhagyásáig. Ugyanakkor megfelelö biztonságérzet adhat, hogy a kamerák jelenléte miatt lehet esély a beavatkozásra. A kamerákat nem kell előtérbe helyezni, megfelelően rejtettek maradhatnak, ugyanakkor jogszabályi elöírás a figyelemfelhívás a jelenlétükre.

\subsection{A kritikus infrastruktúra elemek védelme}

Fontos feladat a 6 . fejezetben meghatározott infrastruktúra elemek megfelelő védelme, illetve működőképességük biztosítása. Egy-egy elem kiesése jelentős károkat okozhat az infrastruktúra használóinak, kezelőjének és így Magyarországnak. A megfelelő védelem az alábbi feladatok megoldásával alakítható ki [21], [22]:

- az irányítási információs rendszer biztonságának növelése, 
- a túlélőképességet növelő műszaki megoldások alkalmazása, amelyeknek elsősorban a mütárgyak esetében van jelentősége,

- a helyettesíthetőség feltételeinek a megteremtése,

- más alágazatra történő átterelés,

- alternatív útvonalak biztosítása.

\subsubsection{Helyettesíthetöség}

Az egyes infrastruktúra elemek kiesése miatti károk enyhítése miatt szükséges megvizsgálni a helyettesíthetőségüket.

A kerülő irányok kijelölése, elemzése során azt is vizsgálni kell, hogy a kijelölt hálózaton milyen vontatási mód üzemel, és ehhez rendelkezünk-e megfelelő vontatómozdonnyal. A vasúti forgalom jelentős része villamosított vonalakon bonyolódik le, ami a sérülékenységet fokozza. Az itt bekövetkezett sérülések hatványozottan befolyásolják a vasút további működőképességét. A kérdés, hogy rendelkezésre állnak-e azok a dízelmozdonyok, amelyek képesek az áramellátó rendszer sérülése esetén átvenni a vontatási feladatokat, illetve a nem villamosított kerülő irányok igénybevételéhez a többi nem villamosított vonal forgalmának jelentős korlátozása nélkül megoldható-e a vontatási feladat. A villamosított vonalak hosszának növekedésével folyamatosan csökken a dízel-vontatójármüvek száma, hiszen a vasúttársaságoknak nem lesz érdekük több dízelmozdony üzemben tartása, csak annyi, amennyit a (dízel)hálózati feladatok ellátása igényel.

A Dunán az egyik legfontosabb tényező a megfelelő számú és területi elosztású hidak megléte. A jelenleg rendelkezésre állók közül a Déli összekötő hídon bonyolódik le az ország teljes kelet-nyugat irányú fövonali tranzitforgalma, így ez az átkelő a hálózat egyik legkritikusabb infrastruktúra eleme. A hídon a fövonali müszaki követelményeknek megfelelő, kétvágányú és villamosított vasúti kapcsolatot építettek ki. A hidat magában foglaló Ferencváros - Kelenföld állomásköz az ország egyik legterheltebb vasúti vonalszakasza, így a vasúti kri- tikus infrastruktúrák hierarchiájában az első helyek egyikét foglalja el. A híd stratégiai jelentőségét mutatja, hogy fegyveres őrök védik.

Az Északi összekötő híd jelentősége a befejezett villamosítás után felértékelődhet, amenynyiben a Dorog - Tokod - Almásfüzitő vonal villamosítása elkészül. Ekkor terelőútvonalaként megfelelő alternatívát nyújthat az $1 \mathrm{sz}$. fövonal.

A Dunán a fővárostól délre legközelebbi magyarországi átkelési pont, vasúton $210 \mathrm{~km}$-re, Bajánál van. A bajai Duna-híd kis forgalmú vonalakat köt össze, a hálózat Budapest-centrikus volta miatt a fö tranzitútvonalak elkerülik, és a két országrész közötti vasúti forgalomban alternatív útirányként csak igen jelentős kerülöútirány igénybevételével lehet figyelembe venni. Stratégiai jelentősége abban áll, hogy a fóvárost elkerülni kénytelen kelet-nyugati irányú vasúti szállítások ezen a hídon keresztül bonyolódnak le.

A fővárostól északra a legközelebbi Duna-híd Komáromnál van. A Dunát átívelő negyedik vasúti híd Komárom és a szlovákiai Révkomárom között biztosít kapcsolatot és Érsekújvárnál csatlakozik a Pozsonyba vezető fővonalhoz. Probléma, hogy használata csak a másik ország engedélyével lehetséges.

A Tiszán a legjelentősebb a Szolnoknál fekvő híd. Az átkelő a Szolnok - Szajol állomásközben található, amely állomásköz forgalma vetekszik a Kelenföld - Ferencváros állomásköz forgalmával, így a vasúti kritikus infrastruktúrák hierarchiájában szintén az első helyek egyikét foglalja el. A szolnoki Tisza- és Zagyva-hidak stratégiai jelentőségét tovább növeli az a tény, hogy jelentős kapacitású tiszai átkelő a közelben nem található. Fegyveres ör ezt a hidat nem védi, erre pedig szükség lenne.

Az előzőekből látható, hogy a budapesti és szolnoki nagyfolyami vasúti hidak az ország vasúti rendszerének meghatározó kritikus infrastruktúra elemi. Helyettesítésük csak új híd építésével lenne biztosítható. 
Az ország vasúthálózatát fő- és mellékvonalak alkotják. A szállítási feladatok végrehajthatóságának érdekében szükséges, hogy a vasúti fővonalat ért sérülés esetén a vasúti kiszolgálás lehetősége a mellékhálózaton keresztül folyamatos maradhasson, függetlenül attól, hogy adott vonalon közlekednek-e személyszállító vonatok.

\subsubsection{A budapesti vasúti átjárhatóság vizs- gálata}

A budapesti vasúti infrastruktúra legnagyobb hiányossága a város többirányú átjárhatatlansága. A Duna keresztezése gyakorlatilag csak a Déli összekötő hídon lehetséges (az Északi összekötő híd szerepe marginális). 2019 elején kezdődött meg az Innovációs és Technológiai Minisztérium felkérésére egy stratégiai dokumentum készítése, amely a budapesti vasúti átjárhatóságot vizsgálja.

Ennek a kritikus infrastruktúrára gyakorolt hatását érintően meg kell vizsgálni a Déli öszszekötő híd melletti egyéb átjárhatósági lehetőséget, többek között a Duna alatti vasúti alagút létesítésének lehetőségét, illetve a „V0” vasútvonal megépítését is.

Az alagút megépítéséhez jelentős vasúti beruházás szükséges, amellyel a Duna alatt még egy átjutási lehetőség létesülne. A fejlesztés eredményeként a teljes budapesti városi körvasúti kapcsolatrendszer létrejöhet, a legnagyobb szabadságot és rugalmasságot biztosítva a városon belüli és városon kívüli viszonylatvezetési alternatíváknak, illetve valós alternatívát adhat a Déli összekötő híd, mint kritikus infrastruktúra elem kiválthatóságára.

Ugyanakkor mind a Duna alatti alagút, mind pedig a „V0” vasútvonal megépítésével további kritikus vasúti infrastruktúra elemek jönnének létre, amelyek védelméről gondoskodni kell, különösképp igaz ez az alagútra. Itt nem lehet majd elhagyni a bejáratoknál a fegyveres örséget, illetve a tervezett földalatti vasútállomás fegyveres védelmét.

Ugyancsak tervezési szinten van már a Liszt Ferenc repülőtér vasúti kiszolgálása is. A meg- épülés után mind a vonal, mind pedig az állomás része kell, hogy legyen a kritikus vasúti infrastruktúrának. A vasútállomás elleni terrorakció nem csak a vasúti közlekedésben, de a légikikötő forgalmában is jelentős fennakadást okozhat, nem beszélve az esetleges jelentős áldozatszámról. Az állomás esetében is szükséges a fegyveres őrzés.

\subsection{A vasúti informatikai rendszerek védelme}

Az európai vasúti hálózat egyik nagy hátránya a rendszer széttagoltsága: az egyes országokban más-más módon történik a forgalom lebonyolítása és irányítása, teljesen eltérőek a jelzési vagy éppen a villamosítási rendszerek, még a nyomtáv sem egységes. Egyetlen „elönyének” az mondható, hogy így nem követhetők el „egyenakciók” a vasutak ellen.

A széttagoltság negatívan hat az európai vasúti szektorra, ezért az EU egyik jelentős törekvése a vasúti hálózat átjárhatóvá tétele. A kölcsönös átjárhatóság egyik alapfeltétele a többáramnemü mozdonyok üzembe állításával megvalósult, nevezetesen már nem kell mozdonyokat cserélni az országhatárokon. A másik alapfeltétellel, az egységes telematikai alrendszerekkel szemben támasztott általános követelmények közül a fontosabbak [21]:

- Biztonság: gondoskodni kell a biztonsággal kapcsolatos információk megbízható és hozzáférhetetlen tárolásáról és továbbításáról.

- Megbízhatóság és üzemkészség: az adatbázisok, szoftverek és kommunikációs protokollok használati, kezelési, aktualizálási és karbantartási módjának biztosítania kell a rendszerek hatékonyságát és a szolgáltatás megfelelő minőségét.

- Müszaki összeegyeztethetőség: az adatbázisok, szoftverek és kommunikációs protokollok fejlesztését úgy kell megoldani, hogy az lehetővé tegye a maximális adatcserét a különböző alkalmazások és üzemeltetők között, kivéve a bizalmas 
kereskedelmi adatok kezelését. Minden jogosult felhasználó számára lehetővé kell tenni az információkhoz való könynyü hozzáférést.

Az egységesítés „hátránya”, hogy így a vasútirányítás homogenizálódik, a rendszer ismerete az egész kontinensen lehetővé teheti terrorakciók elkövetését. Emiatt a rendszer biztonsági elemeinek megfelelőnek kell lenniük, hogy a vonatok közlekedési adatai ne kerülhessenek illetéktelenek kezeibe. A másik fontos biztonsági elem, a kívülről történő behatolás megakadályozása. A biztonság ilyen mérvü megteremtése az egységes európai vasútirányítási rendszerek fejlesztésének fontos feladata.

A korábban említett, különösen veszélyes anyagot szállító vonatok közlekedését operatív módon kell tervezni. Az ilyen vonatok menetrendjét csak a közlekedés előtt rövid idővel készítik el és hozzák az érintettek tudomására. A menetrendet a vonat leközlekedése után meg kell semmisíteni, informatikai tárolás nem lehetséges.

\subsection{A határellenőrzés visszaállítása (schengeni határok megszüntetése)}

Sokszor merül fel problémaként, hogy egy adott országban terrorakciót végrehajtó személyek országba való bejutását kellett volna megakadályozni. Az Európai Unióba történt bejutás után a schengeni övezeten belül a személyek mozgása nincs korlátozva, ugyanakkor az elmúlt időszak eseményei arra késztettek bizonyos országokat, hogy az övezeten belül visszaállítsák a határellenőrzést (pl. Ausztria). A határellenőrzés, ugyan nem vasúti, hanem rendvédelmi eszköz a terrorizmus elleni fellépésben, de hatással van a vasúti közlekedésre és annak menetrendszerüségére, ezért szükséges vele foglalkozni. A határellenőrzés visszaállításával foglalkozik [25] tanulmány.

Amennyiben a határellenőrzést két ország között visszaállítják, akkor ez a vasúti határátkelőkre is vonatkozik, így az ellenőrzéseket a vasúti határállomásokon vagy a vonatokon kell elvégezni.

\subsubsection{A határellenőrzés lehetséges módjai}

Vasúti határellenőrzés végezhető [26]:

- közös határállomáson a két ország szervei által egyszerre,

- határállomáson az adott ország szervei által,

- vonaton menet közben közösen,

- vonaton menet közben az adott ország területén az adott ország szervei által.

A menet közbeni ellenőrzés általában akkor alkalmazható, ha a határállomás nemzetközi utasforgalma alacsony, mert az ott felszálló utasokat a peronon kell ellenőrizni, amit csak a vonaton ellenőrzést végzők tudnak lefolytatni, mert állomási ellenőrző személyzet nincs. Ugyanakkor biztosítani kell, hogy a határállomáson ellenőrzés nélkül senki ne szállhasson fel a külföldre közlekedő vonatra, illetve a külföldről érkező vonatról leszálljon. Menet közbeni ellenőrzéskor azokat a belföldi utasokat is ellenőrzik, akik csak a határállomásig utaznak, de minden állampolgárnak kötelessége türni a hatósági ellenőrzést.

Megoldandó feladat az ellenőrzést végzők eljuttatása arra a vasútállomásra ahol a felszállnak, illetve visszafelé eljuttatásuk a szolgálati helyükre.

\subsubsection{Ellenőrzés a határállomásokon}

A vasút rendeltetésének, berendezéseinek és üzemének sajátossága következtében szükséges, hogy valamennyi része összehangolt legyen, és e részek munkája szigorúan meghatározott módon folyjék. Ezt az összehangolt munkát biztosítja a vonatforgalom menet(idő-) rend szerinti megszervezése. Tekintettel, hogy a vasúti termelési folyamatban igen sok egymástól távol eső, de egymással szoros kapcsolatban müködő dolgozó van, az összehangolást külön eszköz, a menetrend biztosítja, amely a személyszállítási piacon egyben a szolgáltatási kínálat megjelenítése.

Az előzőekben megfogalmazottak miatt a vasúti menetrend betartásának nagy jelentősége van, ezért a menetrend tervezése kulcsfontosságú a vasúti alágazat munkájában. Ennek 
része az egyes állomásokon a vonatok tartózkodási idejének tervezése is. Ide tartozik a határállomási tartózkodási idő megfelelő meghatározása, mert az itt elszenvedett késés jelentős hatással lehet a vonat további útjára: személyszállítás esetén csatlakozások elmulasztása, teherszállítás esetén a termelési folyamat megakadása merülhet fel negatívumként.

A vasúti határállomásokon eltöltött idő tehát jelentős hatással van a menetrendre, a hosszú tartózkodás megnöveli a menetidőt (eljutási időt), a tartózkodási idő túllépése pedig az utasoknak és a fuvaroztatóknak okozhat kellemetlen perceket, órákat (késést). Ezért fontos, hogy a nemzetközi vasúti közlekedés szereplői a vasúti határállomások üzemi folyamatait ismerjék, valamint a tervezés során azok időszükségleteit megfelelően alkalmazzák és betartsák, így segítve elő a nemzetközi forgalomban közlekedő vonatok menetrendszerüségét.

$\mathrm{Az}$ előzőekben megfogalmazott kiemelt összhálózati jelentőség miatt az alkalmazott menetrendi struktúra meghatározhatja, hogy Magyarország felé a vonatoknak mikor kell indulniuk. Ez a meghatározás percértéket jelent, tehát azt, hogy adott vonatnak az óra melyik percében kell elhagynia a határállomást. Ilyen esetekben a szomszéd ország menetrendjén kell változtatni, ha a határállomásra adódó tartózkodási idő nem elegendő, ami a partner vasútvállalat rugalmasságán (és persze lehetőségein) múlik, hogy realizálható-e a kívánt időtartam.

A másik fontos probléma az utasforgalmi csúcsidőszakok kezelése. Alapvetés, hogy a vasúti menetrend egy évre készül.

A csúcsidőszaki jelentős utasszám-növekedés esetén szükséges:

- adott napon az ellenőrző létszám emelése (természetes, hogy ilyenkor a közutakon is megemelkedik az átkelni szándékozók száma),

- esetlegesen mentesítő vonatok közlekedtetése, amelyek menetrendje igazodik a határállomás rendjéhez (általánosságban elmondható, hogy ezeket a vonatokat nem a gyorsaságukért állítják fogalomba),
- utasforgalom terelése a közlekedő vonatok között.

A vasúti határállomások üzemi folyamatait a szállítandó utasok kiszolgálása és az áruk kezelése, valamint a szükséges hatósági ellenőrzési eljárások lefolytatása képezi [27]. Ez a folyamat fö- és melléktevékenységekből, illetve műveletekből áll, amelyek összessége és egymáshoz való kapcsolata az üzemi technológia. Egy-egy üzemi folyamat tervezett idö- és sorrendje az állomási technológia. Az üzemi technológia tehát az adott állomás állomási technológiáinak egymáshoz kapcsolódó rendszere.

Az állomási üzemterv az állomáson lezajló müveletek időben, térben és berendezéseken való lebonyolódását írja le és ábrázolja. Az üzemterv elkészítésekor a folyamattervezés alapjait kell szem előtt tartani. Ez azt jelenti, hogy az adottságokat, a lehetőségeket és a műveleti időket úgy kell egymással összehangolni, hogy a szükségletek optimális kielégítése és a helyes műveleti sorrend, valamint a berendezések optimális kihasználása mellett minimális ráfordítások adódjanak. Ezért a tervezés során törekedni kell a müveletek, müveletcsoportok és részfolyamatok, valamint azok időtartamának, ciklusidejének:

- párhuzamosítására,

- egyidejüsítésére,

- minimalizálására és

- a meddő idők optimalizálásra.

Az összhang megteremtése érdekében egyes műveletek a menetrend által biztosított lehetőség keretein belül eltolhatók, felcserélhetők, vagy megoldási helyük és eszközük megváltoztatható.

\subsubsection{Tehervonatok ellenőrzése}

A teherszállító vonatokat két ok miatt szükséges vizsgálni:

- a vonaton elrejtett olyan robbanószerkezet miatt, amelyet menet közben lehet élesíteni

- a vonaton elbújt személyek miatt, akik így akarnak ki- vagy beszökni. 
Bár ezeknek az előfordulása nem gyakori, de nem is kizárható, így az ellenőrzés lefolytatása szükséges.

A tehervonatok kocsijánál az ellenőrzés során a vám- és vasúti zárat, az azonossági jelet, a vasúti kocsik alvázát, valamint nyitott vagy nyitható kocsik, konténerek esetében a kocsi, konténer belső terét egyszerű szemrevételezéssel kell ellenőrizni.

Konkrét információ, a teherkocsiknál a vámzár, a vasúti zár, az azonossági jel sérülése vagy behatolási nyom észlelése esetén a biztonsági rendszabályok betartása mellett a kocsit a vasút képviselöjével fel kell nyittatni, amelynek tényét és eredményét jegyzőkönyvben rögzíteni kell.

A kutatás során fontos, hogy minden olyan részt megvizsgáljanak, ahova lehetséges elbújni. Ilyenek lehetnek a vasúti forgózsámolyok egyes elemei, a vasúti kocsi fékezőhelyiségei, az üres teherkocsik (akár tartálykocsik is), a rakott teherkocsik szabad részei, felületei, a konténerek belső terei, stb.

\subsubsection{A müködőképesség megőrzése}

Fontos kérdés, hogy a határellenőrzés visszaállítása esetén mennyire lehet a működőképességet megörizni. Kijelenthető, hogy a személyszállítási terület nem visel el semmiféle adminisztratív jellegű menetidő növekedést (tegyük hozzá, hogy igazából semmilyet sem). A menetidők további növekedése már negatív irányban hat az utasszámokra, így a vasúttársaságok célja nem lehet a határtartózkodás növelése. Ez azt jelenti, hogy a jelenlegi határállomási tartózkodási idők az irányadók, sőt a távlati célok között szerepel a kisforgalmú határátkelökön a megállás megszüntetése. A határállomásokon való megállás nélküli áthaladás technikai megvalósításán már dolgoznak a vasúttársaságok és az infrastruktúra-kezelők.

Hogy oldható meg ebben az esetben a szükséges határellenőrzés? A válasz a menet közbeni ellenőrzés biztosítása lehet, ennek lehetőségét minden határátmenetben meg kell teremteni. $\mathrm{Az}$ ehhez szükséges infrastruktúrát: mobil okmány- és ujjlenyomatolvasó berendezéseket szükséges beszerezni, illetve ki kell alakítani a szükséges előállító objektumokat és az ellenőrző szervek megfelelő ellátását szolgáló helyiségeket azokon az állomásokon, ahol a vonatok a határ előtt vagy után először megállnak.

Tehervonatok esetében is cél a határállomási tartózkodás csökkentése. A nemzetközi áruszállítási folyosókon közlekedő tehervonatok esetében a vasútvállalatok törekvései is szintén ebbe az irányba hatnak. Ugyanakkor az EU sürgeti olyan vasútvonalak kialakítását, ahol a tehervonatok elsőbbséget élveznek a személyvonatokkal szemben, így az áruszállítás sebessége nagymértékben növelhető. Ez nem tesz lehetővé hosszú határtartózkodást.

A biztonság érdekében azonban szükséges lehet a tehervonatok átvizsgálása az előző pontban ismertetettek miatt. A vizsgálat idejét minimalizálni, és az ehhez szükséges felszereléseket, valamint ellenőrzési létszámot biztosítani kell.

\section{8. ÖSSZEFOGLALÁS}

$\mathrm{Az}$ emberi élet a legfőbb érték. A terrortámadások célja leginkább emberéletek kioltása és ezáltal félelemkeltés, a rettegés fokának fenntartása. Erre megfelelö terep a közösségi közlekedés, mert tömegszerüsége miatt az áldozatszám maximalizálható, így egy terrorakció megfelelö „sikert” érhet el. Ezért fontos, hogy megfelelő intézkedésekkel ezeket az akciókat megakadályozhassuk, így sok ember életét, azaz a legfőbb értéket menthessük meg.

Az akciók megakadályozása mellett a másik fontos dolog a biztonságérzet fenntartása. Az emberek akkor használnak szívesen valamilyen közösségi közlekedési eszközt, ha azt biztonságosnak érzik (mind közlekedésbiztonsági, mind élet- és vagyonbiztonsági szempontból). A terroristák sokszor megelégszenek a támadási lehetőség, így a félelemérzet fenntartásával.

A cikk elsőként foglalja össze a vasúti közlekedési rendszer biztonságfilozófiájából adódó, valamint a vasút területén bevezethető megol- 
dásokat, amelyekkel a terrortámadások megelőzhetők, vagy kockázatuk mértéke jelentősen csökkenthető.

A 3. fejezetben leírtak alapján a vasút már önmagában is a biztonságfilozófiájával, a berendezések kialakításával, utasításainak rendszerével képes egyfajta biztonságot nyújtani, de ez elsősorban a közlekedés biztonságát jelöli. Ugyanakkor ez alkalmas lehet a terrorakciók megakadályozására, amennyiben a vasúti alkalmazottak tudásszintje is megfelelö, és képesek a helyes döntések meghozatalára egyes rendkívüli helyzetekben. Ennek elérése érdekében szükséges az állomány folyamatos képzése és tudásának szinten tartása. Fontos feladat hárul tehát a vasúti képzéssel foglalkozó intézményekre, hogy képzési tervükbe beépítsék a rendkívüli helyzetek kezelésének oktatását.

A cikkben bemutatott megoldások: a beléptetökapuk telepítése, a csomag- és a fedélzeti ellenőrzés megszervezése, a kritikus infrastruktúra elemek és a vasúti biztonsági rendszerek elégséges védelme, az egyes infrastruktúra elemek megfelelő helyettesíthetősége, valamint az esetlegesen szükséges határellenőrzés megfelelő megszervezése mind-mind elösegíthetik a terrorakciók végrehajtásának megakadályozását, a biztonság megfelelő szinten tartását és a károk enyhítését. Adott berendezések megrendelése és legyártatása az adott infrastruktúrakezelő társaságok feladata, illetve a helyettesíthetőség kérdését tervezni kell. A vasúti infrastruktúra tervezőinek feladata a(z új) kritikus vasúti infrastruktúra elemek helyettesíthetőségének megoldása.

Megfelelő kockázatelemzési számításokat kell elvégezni annak érdekében, hogy kiderüljön melyik vasútállomásra vagy megállóhelyre kell telepíteni beléptetőkapukat esetleg csomagellenőrző berendezéseket és melyik infrastruktúra elemet kell védeni fegyveres őrrel. A különböző kockázatelemzési eljárások szakirodalmát mutatja be a [18] tanulmány. $\mathrm{Az}$ esetlegesen felmerülő fegyveres örzés feladatinak megszervezése a rendvédelmi szervek hatáskörébe tartozik.
A kritikus infrastruktúra elemekkel kapcsolatban ki kell jelölni, hogy mely más elemek tekinthetők helyettesítő elemnek, merre vezetnek a kerülő útirányok, és ezen meghatározott elemek karbantartását fokozottabban kell végezni.

A kiberterrorizmus elleni megfelelő védelem: a tüzfalak felállítása és a behatolás megakadályozása a szoftvergyártóktól követel nagyobb figyelmet. A vasúti rendszereket irányító számítógépes programok esetében el kell érni, hogy illetéktelenek ne tudjanak a rendszerhez hozzáférni vagy abból adatokat megszerezni.

Ugyanakkor nem lehet itt befejezni a munkát, ezért további kutatások szükségesek, hogy a terrorizmus elleni küzdelem még sikeresebb lehessen és még több embert tudjunk biztonságban elszállítani. Itt jönnek szóba a védelmi szakemberek feladatai, amelyek közül a legfontosabb a közlekedés és a védelmi képesség összhangjának megteremtése. A cikk ezen kutatások alapjául szolgálhat.

A vázolt megoldások ugyanakkor egy jelentős kérdést nyitva hagynak: ez pedig a biztonság ára. A javaslatok megvalósítása jelentős öszszegbe kerülhet. Az egyes közlekedési vállalatok, kormányok döntésein múlik, hogy mennyit hajlandók áldozni az utasaik, illetve az állampolgárok biztonságára és biztonságérzetének fenntartására.

Látható tehát, hogy a vasúti közlekedés biztonságossá tételéhez sok szakember együttes munkája szükséges. Ha a címben is megfogalmazott lehetőségekkel élünk, akkor elmondhatjuk, hogy tettünk egy (nagy) lépést a vasúti szektor, mint biztonságos közlekedési alágazat irányába.

\section{FELHASZNÁLT IRODALOM}

[1] Horváth A.: Nyilvánosság és térjellemzők a létfontosságú rendszerek védelmében, In. Horváth A. - Bányász P. - Orbók Á. (szerk.) Fejezetek a létfontosságú közlekedési rendszerelemek védelmének aktuális kérdéseiről, Tanulmánykötet, NKE, Budapest, 2014. pp 7-26. 
[2] Horváth A.: A kritikus infrastruktúra védelem komplex értelmezésének szükségessége, In. Horváth A. (szerk.) Fejezetek a kritikus infrastruktúra védelemből - Kiemelten a közlekedési alrendszer, Tanulmánykötet, Magyar Hadtudományi Társaság, Budapest, 2013. pp. 18-37.

[3] Horváth A.: Terrorfenyegetettség: célpontok, nagyvárosok, közlekedés, Nemzetvédelmi Egyetemi Közlemények 10 (3.). pp. 136-152. on-line letöltés, https:// docplayer.hu/5050108-Terrorfenyegetettsegcelpontok-nagyvarosok-kozlekedes-aterrorfenyegetettseg-altalanos-jellemzoihorvath-attila-1.html, letöltve: 2018.12.29.

[4] Horváth A.: Közlekedési hálózat és az ország védelmi képesség kapcsolata (védelmi követelmények a közlekedésfejlesztésben), megjelent: biztonsagpolitika.hu, 2009.01.16., pp. 1-9., on-line letöltés, http:// old.biztonsagpolitika.hu/documents/ 1277414270_horvath_attila_kozlekedesi_ halozat_es_az_orszag_vedelem_kepesseg_ kapcsolata_-_biztonsagpolitika.hu.pdf, letöltve: 2018.12.29.

[5] Horváth A.: A vasúti közlekedés terrorfenyegetettségének jellemzői a városokban, Hadmérnök, IV. évf. 3. szám, 2009. szeptember, pp. 180-189, on-line letöltés, http:// hadmernok.hu/2009_3_horvatha.pdf, letöltve: 2018.12.29.

[6] Szternák Gy. - Kiss Z. L.: Vázlat a terrorizmus szociológiai aspektusainak vizsgálatához, on-line letöltés http://m.ludita.uni-nke.hu/ repozitorium/bitstream/handle/11410/1062/ Szternak3.pdf? sequence $=1 \&$ isAllowed $=y$, pp. 106-145, letöltve: 2018.12.29.

[7] Dr. Horváth A.: A felszíni közlekedés terrorfenyegetettsége és a védelem lehetőségei, on-line letöltés: http://kitt.uni-obuda. $\mathrm{hu} / \mathrm{mmaws} / 2007 /$ download/DrHorvath_ IFFK.pdf, oldalszámozás nélkül, letöltve: 2018.12.29.

[8] Lévai Zs.: A vasúti közlekedés biztonsága, egyetemi tansegédlet, NKE, HHK, 2018

[9] Lévai Zs.: Közlekedésinformatika - vasúti közlekedésirányítási rendszerek, egyetemi tansegédlet, NKE HHK, 2018

[10] Arató K.: Vasúti rendszertechnikai ismeretek (elektronikus jegyzet), Széchenyi István Egyetem
[11] http://ertms.hu/?id=ertms

[12] Olasz P.: Mi is az az ETCS? HTE INFOKOM 2014 - LXIX. évfolyam

[13] Fábos R.: A közlekedési informatikai rendszerek sérülékenysége, In. Horváth A. (szerk.) Fejezetek a kritikus infrastruktúra védelemből - Kiemelten a közlekedési alrendszer, Tanulmánykötet, Magyar Hadtudományi Társaság, Budapest, 2013. pp. 191225.

[14] Dr. Horváth A.: A londoni közösségi közlekedési rendszer elleni terrortámadások 2007-ben, Hadtudományi Szemle, 3. évfolyam 2. szám, Budapest, 2010. on-line letöltés, http://epa.oszk.hu/02400/02463/00009/ pdf/EPA02463_hadtudomanyi_szemle_2010_2_059-069.pdf, letöltve: 2018.12.29.

[15] HVG: Oroszországi terror: merényletkronológia Csecsenföldtől az Iszlám Államig, on-line cikk, megjelent: hvg.hu, 2017.04.03., https://hvg.hu/vilag/20170403_ Oroszorszag_a_terror_arnyekaban merenyletkronologia_Csecsenfoldtol_az_ Iszlam_Allamig, letöltve: 2019.01.02.

[16] 24.hu: Az elmúlt 13 év legsúlyosabb terrorcselekményei, on-line cikk, megjelent: 24.hu, 2015.11.14., https://24.hu/ kulfold/2015/11/14/az-elmult-13-evlegsulyosabb-terrorcselekmenyei/, letöltve: 2019.01.02.

[17] Index: Terrortámadás a vonaton: az utasokon múlt, on-line cikk, megjelent: index.hu, 2015.08.22., https://index.hu/ kulfold/2015/08/22/az_utasok_batorsagan_ mult_hogy_nem_lett_nagyobb_tragedia/, letöltve: 2019.01.02.

[18] Ronyecz L.: Létfontosságú rendszerek és létesítmények védelmével kapcsolatos kockázatelemzési módszertan szakirodalmának bemutatása, Védelem Tudomány, III. évf. 3. szám, pp. 112-132, 2018. szeptember, online letöltés, http://vedelemtudomany.hu/ articles/08-ronyecz.pdf, letöltve: 2018.12.29.

[19] Endrődi I.: A közlekedési ágazat kritikus infrastruktúra elemei, kapcsolatuk a katasztrófavédelemmel, figyelemmel az Európai Unió Kritikus Infrastruktúrák Azonosításáról és Kijelöléséről szóló 2008. évi 2008/114/EK Tanácsi Irányelvében megfogalmazottakra, In. Horváth A. (szerk.) Fejezetek a kritikus infrastruktúra védelemből - Kiemelten a 
közlekedési alrendszer, Tanulmánykötet, Magyar Hadtudományi Társaság, Budapest, 2013. pp. 238-267.

[20] Bonnyai T.: Úton a kritikus információs infrastruktúrák azonosítása és védelmük kialakítása felé, Hadmérnök, VII. évf. 2. szám, pp. 90-105, 2012. június, on-line letöltés, http:// hadmernok.hu/2012_2_bonnyai.pdf, letöltve: 2018.12.29.

[21] Szászi G.: A vasúti közlekedési alágazat, mint kritikus infrastruktúra, In. Horváth A. (szerk.) Fejezetek a kritikus infrastruktúra védelemböl - Kiemelten a közlekedési alrendszer, Tanulmánykötet, Magyar Hadtudományi Társaság, Budapest, 2013. pp. 167-190.

[22] Szászi G. mk. alezredes: A vasúti hálózati infrastruktúrával szemben támasztott újszerü védelmi követelmények kutatása, a továbbfejlesztés feltételrendszerének vizsgálata, Doktori $(\mathrm{PhD})$ értekezés, $\mathrm{NKE}, \mathrm{Bu}-$ dapest, 2013.

[23] Lukács J.: Állomási beléptető kapuk elhelyezésének vizsgálata budapesti metróhá- lózaton (diplomaterv), BME KJK, Budapest, 2014., on-line letöltés, http://www. kjit.bme.hu/images/trafficlab/Publication/ thesis/2014/Lukacs_J_2015_dipl.pdf, letöltve: 2019.01 .01 .

[24] MNO: Amerikában is vitatják a légimarsallok szükségességét, on-line cikk, megjelent: mno.hu, 2004.01.10., https:// mno.hu/migr_1834/amerikaban-is-vitatjaka-legimarsallok-szuksegesseget-648394 (tárolt változat), letöltve: 2019.01.02.

[25] Balla J.: A határellenőrzés ideiglenes visszaállításának támogatása, erő-eszköz szükséglete, Határrendészeti Tanulmányok, XV. évf. 2. szám, pp. 4-28. Budapest, 2018., on-line letöltés, https://rtk.uni-nke.hu/document/rtkuni-nke-hu/Hatrend\%20Tan_2018_2\%20 sz\%C3\%A1m.pdf, letöltve: 2019.01.14.

[26] Lévai Zs.: Vasúti határállomások és munkafolyamataik, egyetemi tansegédlet, NKE RTK, 2018.

[27] Lévai Zs.: Vasúti üzemtan, egyetemi tansegédlet, NKE HHK, 2018

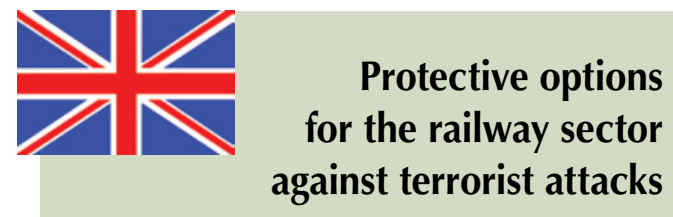

The rail sector, as an element of the transport system, can be a "soft target" for terrorists to carry out their actions. Easy access, the large number of passengers, the transport of heavy (sometimes dangerous) goods and the expected high number of victims can all easily motivate terrorist groups to carry out their actions on the railways. Because of the above, protection is necessary and expected, both by the traveling public, by the carriers, and by the state.

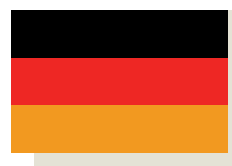

\section{Schutzoptionen für den Eisenbahnsektor gegen Terroranschläge}

Der Eisenbahnsektor kann als Element des Verkehrssystems ein "weiches Ziel" für Terroristen sein, um ihre Aktionen auszuführen. Einfacher Zugang, die große Anzahl von Passagieren, der Transport schwerer (manchmal gefährlicher) Güter und die erwartete hohe Anzahl von Opfern können terroristische Gruppen leicht dazu motivieren, ihre Aktionen auf der Eisenbahn durchzuführen. Aus diesen Gründen ist der Schutz sowohl für das reisende Publikum als auch für die Transportunternehmen und den Staat erforderlich und erwartet. 